\title{
A protein that shuttles between the nucleus and the cytoplasm is an important mediator of RNA export
}

\author{
Margaret S. Lee, Michael Henry, and Pamela A. Silver ${ }^{1}$ \\ Department of Biological Chemistry and Molecular Pharmacology, Harvard Medical School and Division of Cellular and \\ Molecular Biology, Dana-Farber Cancer Institute, Boston, Massachusetts 02115 USA
}

The connection between RNA and protein export from the nucleus was examined in the budding yeast Saccharomyces cerevisiae. NPL3 encodes an RNA-binding protein that shuttles in and out of the nucleus. Export of poly(A) $)^{+}$RNA has been shown previously to be blocked in npl3-1 mutants. To understand the role of Npl3p in RNA export, we have developed a novel assay that effectively uncouples nuclear protein export from reimport. With this assay, we show that Npl3p satisfies several of the predicted requirements for a protein carrier for mRNA export. Temperature-sensitive mutations in the RNA recognition motifs of Npl3p result in nuclear accumulation of poly $(A)^{+}$RNA. One such mutation prevents nuclear export of Npl3p. Moreover, Npl3p export depends on ongoing RNA polymerase II transcription. Export ceases in either the presence of the RNA synthesis inhibitor thiolutin or in a temperature-sensitive RNA polymerase (rpb1) mutant. Together, these findings support a model in which Npl3p exits the nucleus in association with poly $(A)^{+}$RNA, deposits the RNA in the cytoplasm, and is rapidly reimported for another cycle of export.

[Key Words: NPL3; poly $(\mathrm{A})^{+} \mathrm{RNA}$; nuclear export; shuttling; hnRNP]

Received December 19, 1995; revised version accepted March 29, 1996.

RNA export from the nucleus is a facilitated energy-dependent process in which specific factors may mediate the export of certain RNAs (Zasloff 1983; Bataille et al. 1990; Dargemont and Kuhn 1992; Jarmolowski et al. 1994). It is likely that all RNAs exit the nucleus in association with RNA-binding proteins and that the substrate for export is not naked RNA but, instead, an RNP complex (for review, see Mehlin and Daneholt 1993). A recent study has shown that the Chironomous tentans pre-mRNA-binding protein Hrp36 is part of a large premRNP complex that accompanies RNA from the site of transcription, through the nuclear pore complex, and into polysomes (Visa et al. 1996).

One of the most abundant classes of nuclear RNAbinding proteins is the heterogeneous nuclear ribonucleoproteins ( $h n R N P$ ), a family of proteins with proposed roles in multiple steps of mRNA processing and export (for review, see Dreyfuss et al. 1993). hnRNPs have been identified in most eukaryotes, including the budding yeast Saccharomyces cerevisiae (Bossie et al. 1992; Anderson et al. 1993; Wilson et al. 1994; Henry et al. 1996). The study of hnRNPs has uncovered a common structural theme: one or more RNA-binding domains and at least one other auxiliary domain proposed to mediate protein interactions. The RNP-type RNA-recognition motif (RRM) present in a number of RNA-binding

\footnotetext{
${ }^{1}$ Corresponding author.
}

proteins is a domain of $\sim 90$ amino acids that contains two consensus sequences, RNP-1 and RNP-2 (Dreyfuss et al. 1988; Bandziulis et al. 1989; Kenan et al. 1991; Haynes 1992; Mattaj 1993).

Some nuclear proteins, including hnRNP proteins, exit the nucleus and rapidly re-enter in a process referred to as nucleocytoplasmic shuttling. Although the functional significance of this phenomenon is not yet clear, it has been proposed to be part of the mechanism for the exchange of RNAs between the nucleus and the cytoplasm (Piñol-Roma and Dreyfuss 1992; Piñol-Roma and Dreyfuss 1993; Flach et al. 1994). Specific nuclear export signals (NESs) have now been shown to exist in the cellular proteins hnRNP Al (Michael et al. 1995) and the protein kinase A inhibitor peptide (PKI; Wen et al. 1995) as well as the viral protein Rev (Fischer et al. 1995), suggesting that protein export is an active, signal-mediated pathway. The existence of specific export signals in proteins that bind RNA (i.e., hnRNP Al and rev) strengthens the argument that shuttling hnRNPs act as carriers for RNA export.

The NPL3 gene was originally isolated as a temperature-sensitive mutant defective in nuclear protein localization (Bossie et al. 1992). The same NPL3 mutants accumulate poly $(\mathrm{A})^{+}$RNA in the nucleus at the nonpermissive temperature indicating a block in mRNA export (Russell and Tollervey 1995; Singleton et al. 1995; Henry et al. 1996). 
The NPL3 gene encodes a nuclear protein that shuttles between the nucleus and the cytoplasm in the budding yeast (Bossie et al. 1992; Russell and Tollervey 1992; Flach et al. 1994; Wilson et al. 1994). Npl3p is relatively abundant and can be cross-linked to poly(A) ${ }^{+}$RNA (Wilson et al. 1994). Moreover, Npl3p has structural features analogous to those found in some hnRNP proteins including two central RRMs flanked by a carboxy-terminal glycine-rich domain containing a series of RGGY/F repeats. Npl3p also shows some similarity to three members of an evolutionarily conserved family of alternative splicing factors termed SR proteins and is, to date, the only SR-like protein in yeast (Birney et al. 1993). Alignment of the RRMs of Npl3p with human SF2/ASF, Drosophila SRp55, and Arabidopsis SR protein reveals homologies far greater than those expected for unrelated RRMs.

We propose that Npl3p may participate directly in the process of mRNA export by acting as a carrier of mRNA as it is transported to the cytoplasm via the nuclear pore. The requirements for such a carrier, in principle, include the following: It should bind RNA in the nucleus, move out of the nucleus with RNA, and return to the nucleus from the cytoplasm. To demonstrate that Npl3p meets these criteria, we now report a new assay for nuclear export. Previous assays for nucleocytoplasmic shuttling required the formation of heterokaryons and the movement of protein from one nucleus to the other; thus uptake into a second nucleus was required for exit from the first to be assayed. The assay we now present uncouples the process of nuclear export from reimport. Using this assay, we present several lines of evidence to show that Npl3p and poly(A) ${ }^{+}$RNA export are tightly coupled. First, new mutations in the RRMs of Npl3p result in defects in poly $(\mathrm{A})^{+}$RNA export from the nucleus; second, a mutation in the first RRM of $\mathrm{Npl} 3 \mathrm{p}$ results in a block in Npl3p export; and third, the export of Npl3p from the nucleus is dependent on RNA polymerase II transcription. We propose a model in which Npl3p must form a complex with poly $(A)^{+}$RNA for nuclear export to occur.

\section{Results}

New NPL3 temperature-sensitive mutants display Npl3p import and RNA export defects

In wild-type cells, Npl3p is located in the nucleus as determined by immunofluorescence, at all growth temperatures tested (Fig. 1A, top row; Bossie et al. 1992). We know, however, that Npl3p is capable of exiting and reentering the nucleus (Flach et al. 1994). Thus, the observed steady-state nuclear location of Npl3p indicates that it must shuttle rapidly between the nucleus and the cytoplasm. In addition, in wild-type cells, the poly $(\mathrm{A})^{+}$ RNA is distributed diffusely throughout the cytoplasm as determined by in situ analysis at all growth temperatures tested (Fig. 1A, top row) and is consistent with rapid RNA export out of the nucleus (Amberg et al. 1992).
To obtain more information about the functional domains of $\mathrm{Npl} 3 \mathrm{p}$, we generated a panel of new temperature-sensitive npl3 mutants. These mutants were isolated solely on the basis of their failure to grow on plates at $37^{\circ} \mathrm{C}$. Further analysis of the resulting mutations and their phenotypes showed a relationship between mutations in the RRMs of Npl3p, defects in poly $(\mathrm{A})^{+}$RNA export from the nucleus, and temperature-sensitive growth. Three phenotypic classes of mutants were identified on the basis of Npl3p protein and poly $(\mathrm{A})^{+}$RNA localization.

Those in the first class show defects in Npl3p localization at permissive temperatures and accumulation of poly $(\mathrm{A})^{+}$RNA in the nucleus at the restrictive temperature. One member of this class is the previously described mutant npl3-1 (Bossie et al. 1992; Kadowaki et al. 1994a; Singleton et al. 1995). This mutant shows severe mislocalization of $\mathrm{Npl} 3 \mathrm{p}$ to the cytoplasm at $30^{\circ} \mathrm{C}$, a temperature that is semipermissive for growth (Fig. 1B; Bossie et al. 1992). Interestingly, at $37^{\circ} \mathrm{C}$, the temperature at which npl3-1 cells display a poly $(\mathrm{A})^{+}$RNA export defect and are incapable of growth, Npl3p is localized primarily in the nucleus of the cell (Fig. 1). As shown in Table 1, a similar pattern of Npl3p mislocalization at $30^{\circ} \mathrm{C}$ and poly $(\mathrm{A})^{+}$RNA accumulation in the nucleus at $37^{\circ} \mathrm{C}$ is seen in $n p 13-1, n p 13-38$, and npl3-48, each of which contains a mutation within the second RNA recognition motif of Npl3p (RRM2; Fig. 2). The first appearance of the RNA export defect in these cells is apparent $1 \mathrm{hr}$ after a shift to $37^{\circ} \mathrm{C}$ and is maximal at $3 \mathrm{hr}$. The mutant npl3-26 also contains a mutation in RRM2 but displays a much weaker phenotype of Npl3p mislocalization and poly $(\mathrm{A})^{+}$RNA accumulation in the nucleus, with the latter defect first appearing $3 \mathrm{hr}$ after a shift to $37^{\circ} \mathrm{C}$ and becoming maximal at $6 \mathrm{hr}$.

Three of the mutants fall into the second class and show little or no defect in Npl3p localization at any temperature tested but display accumulation of poly $|A|^{+}$ RNA in the nucleus at $30^{\circ} \mathrm{C}$ as well as at $37^{\circ} \mathrm{C}$ (Table 1 ). These mutants include npl3-3, npl3-17, and npl3-41. Each contains at least one mutation in the first RRM of Npl3p (RRM1), and npl3-17 also contains a mutation in RRM2. Accumulation of poly $(A)^{+}$RNA in the nucleus of these cells is first observed as early as 30 min after a shift to the nonpermissive temperature (Fig. 1; Table 1).

Although all of the mutants in classes 1 and 2 display some degree of nuclear accumulation of poly $(A)^{+}$RNA, they also display some cytoplasmic RNA signal. This result suggests that in no case is there a complete block in $\operatorname{poly}(\mathrm{A})^{+}$RNA export. Only one of the mutants analyzed, npl3-27, did not display any accumulation of poly $\mid A)^{+}$RNA in the nucleus. This mutant did, however, show defects in Npl3p localization, even at the permissive temperature of $25^{\circ} \mathrm{C}$. Although npl3-27 cells fail to grow at $37^{\circ} \mathrm{C}$ on plates (data not shown), they are capable of logarithmic growth in liquid culture for at least $16 \mathrm{hr}$ after a shift to $37^{\circ} \mathrm{C}$ (Fig. 1B). This allele of NPL3 contains one mutation in the carboxy-terminal RGG box domain of Npl3p and is the sole member of the third class (Fig. 1; Table 1). It should also be noted that 

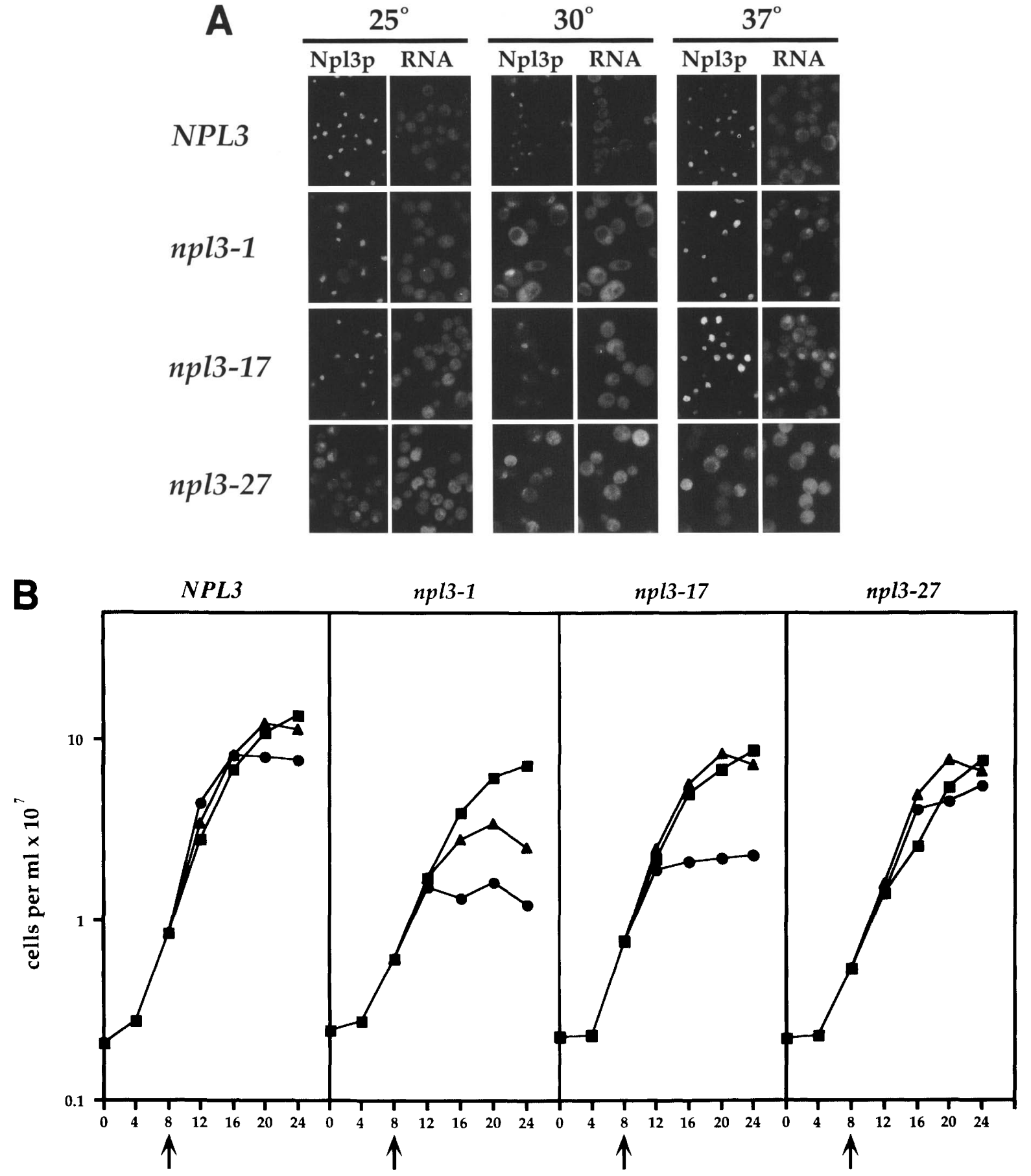

\section{Time (hours)}

Figure 1. Characterization of $n p l 3$ temperature-sensitive mutants. $(A)$ Localization of Npl3p and poly $(\mathrm{A})^{+}$RNA in npl3 temperaturesensitive mutants. Strains were grown to $1 \times 10^{7}$ cells $/ \mathrm{ml}$ in SC medium lacking leucine and shifted to $30^{\circ} \mathrm{C}$ (middle columns), $37^{\circ} \mathrm{C}$ (right columns), or incubated at $25^{\circ} \mathrm{C}$ (left columns) for an additional $4 \mathrm{hr}$ (or $8 \mathrm{hr}$ for wild-type $N P L 3$ at $37^{\circ} \mathrm{C}$. The Npl3p protein was visualized with an FITC anti-rabbit secondary antibody, and the RNA was visualized with the Texas Red sheep anti-digoxigen Fab fragment. $(B)$ Growth curves of npl3 temperature-sensitive mutants. Overnight cultures of strains containing wild-type NPL3, or temperature-sensitive alleles of npl3, were diluted into fresh medium and incubated for $8 \mathrm{hr}$ at $25^{\circ} \mathrm{C}$ ( $\square$ ). Cultures were then shifted (arrow) to either $30^{\circ} \mathrm{C}(\mathbf{O})$ or $37^{\circ} \mathrm{C}(\mathbf{\Delta})$, and growth curves were generated by counting of cells every $4 \mathrm{hr}$. 
Table 1. Summary of NPL3 mutations and phenotypes

\begin{tabular}{|c|c|c|c|c|c|c|c|c|}
\hline \multirow[b]{2}{*}{ Allele } & \multirow[b]{2}{*}{ Mutation $^{a}$} & \multirow[b]{2}{*}{ Domain $^{b}$} & \multicolumn{3}{|c|}{$\begin{array}{l}\text { Npl3p mislocalization } \\
\qquad\left({ }^{\circ} \mathrm{C}\right)\end{array}$} & \multicolumn{3}{|c|}{$\begin{array}{c}\text { Nuclear accumulation } \\
\text { of poly }(\mathrm{A})^{+} \text {RNA } \\
\left({ }^{\circ} \mathrm{C}\right)\end{array}$} \\
\hline & & & 25 & 30 & 37 & 25 & 30 & 37 \\
\hline \multicolumn{9}{|l|}{ Class 1} \\
\hline npl3-1 & A254V & RRM2 & + & ++ & + & - & - & ++ \\
\hline npl3-26 & N223D & RRM2 & + & - & - & - & - & + \\
\hline npl3-38 & G24lD & RRM2 & + & + & - & - & - & ++ \\
\hline np13-48 & S230P & RRM2 & + & ++ & - & - & - & ++ \\
\hline \multicolumn{9}{|l|}{ Class 2} \\
\hline np13-3 & S193P & RRMl & - & - & - & + & + & ++ \\
\hline \multirow[t]{2}{*}{ npl3-17 } & F160L & RRMl & + & + & - & - & + & ++ \\
\hline & $\mathrm{I} 268 \mathrm{~T}$ & RRM2 & & & & & & \\
\hline \multirow[t]{3}{*}{ np13-41 } & E121G & N-term & - & - & - & + & + & ++ \\
\hline & F183I & RRMl & & & & & & \\
\hline & S193P & RRMl & & & & & & \\
\hline \multicolumn{9}{|l|}{ Class 3} \\
\hline np13-27 & E409K & RGGY & ++ & ++ & ++ & - & - & - \\
\hline
\end{tabular}

Phenotypes are described as approximate number of cells displaying the defect either Npl3p mislocalization to the cytoplasm or accumulation of RNA in the nucleus. $|+| 0 \%-50 \% ; 1++\mid 50 \%-100 \%$.

${ }^{a}$ Amino acid changes are described using the one-letter amino acid code with the first letter indicating the wild-type amino acid followed by its number and the amino acid to which it is changed in the mutant.

${ }^{\mathrm{b}}$ The domain in which the mutation is present.

for all of the mutants tested, the level of the mutant $\mathrm{Npl3}$ protein is unchanged after temperature shift, as determined by Western blotting of total protein from cell extracts (not shown).

\section{A new assay for Npl3p nuclear export}

To study the relationship between Npl3p and RNA nuclear export, we needed to devise a new assay that effectively uncoupled the two processes from nuclear protein import. A previous assay employed the formation of yeast heterokaryons, where the readout is the re-uptake of a shuttling protein into a second nucleus (Flach et al. 1994). In addition, because the formation of heterokary- ons requires the mating of two yeast strains, there is inherent technical difficulty in generating heterokaryons in the absence of RNA synthesis or when temperaturesensitive mutants are used. For example, there is ample time for cytoplasmic mixing to occur, which could result in rescue of a recessive mutation. Therefore, we designed a new experimental system to examine specifically the process of protein export in the absence of reimport (Fig. 3A).

Our experimental system is based on the fact that the nucleoporin mutant nup49-313 is defective in nuclear protein import at the nonpermissive temperature of $36^{\circ} \mathrm{C}$ but exports RNA under these conditions (Schlenstedt et al. 1993; Doye et al. 1994). When nup49-313 cells are
Figure 2. Schematic diagram of $n p 13$ temperature-sensitive mutations. The two RRMs of Npl3p are represented. Underlined residues are conserved with members of the SR family of alternative splicing factors. Residues marked with an asterisk are present in a consensus sequence for RRMs (Birney et al. 1993). The highly conserved RNP-1 and RNP-2 motifs are indicated. Amino acid substitutions found in the temperature-sensitive mutants generated in this study are indicated with arrows. Also indicated are the previously identified mutants np13-1 (Bossie et al. 1992; Kadowaki et al. 1994c; Singleton et al. 1995), npl3-328 (Bossie et al. 1992; Henry et al. 1996), and np13-95 (Loo et al. 1995; Russell and Tollervey 1995; Henry et al. 1996).
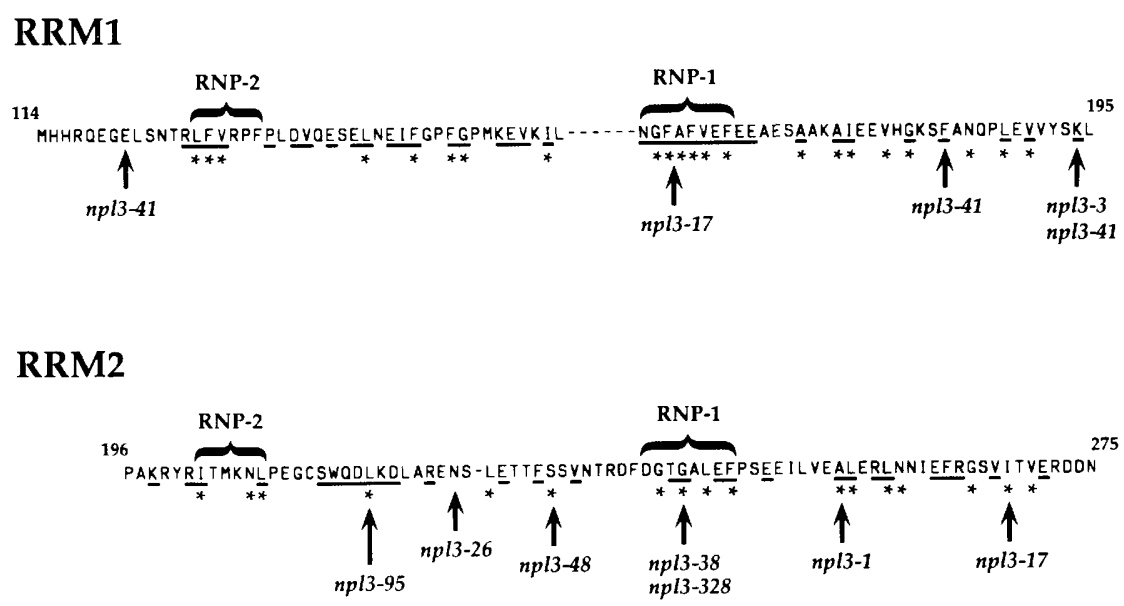


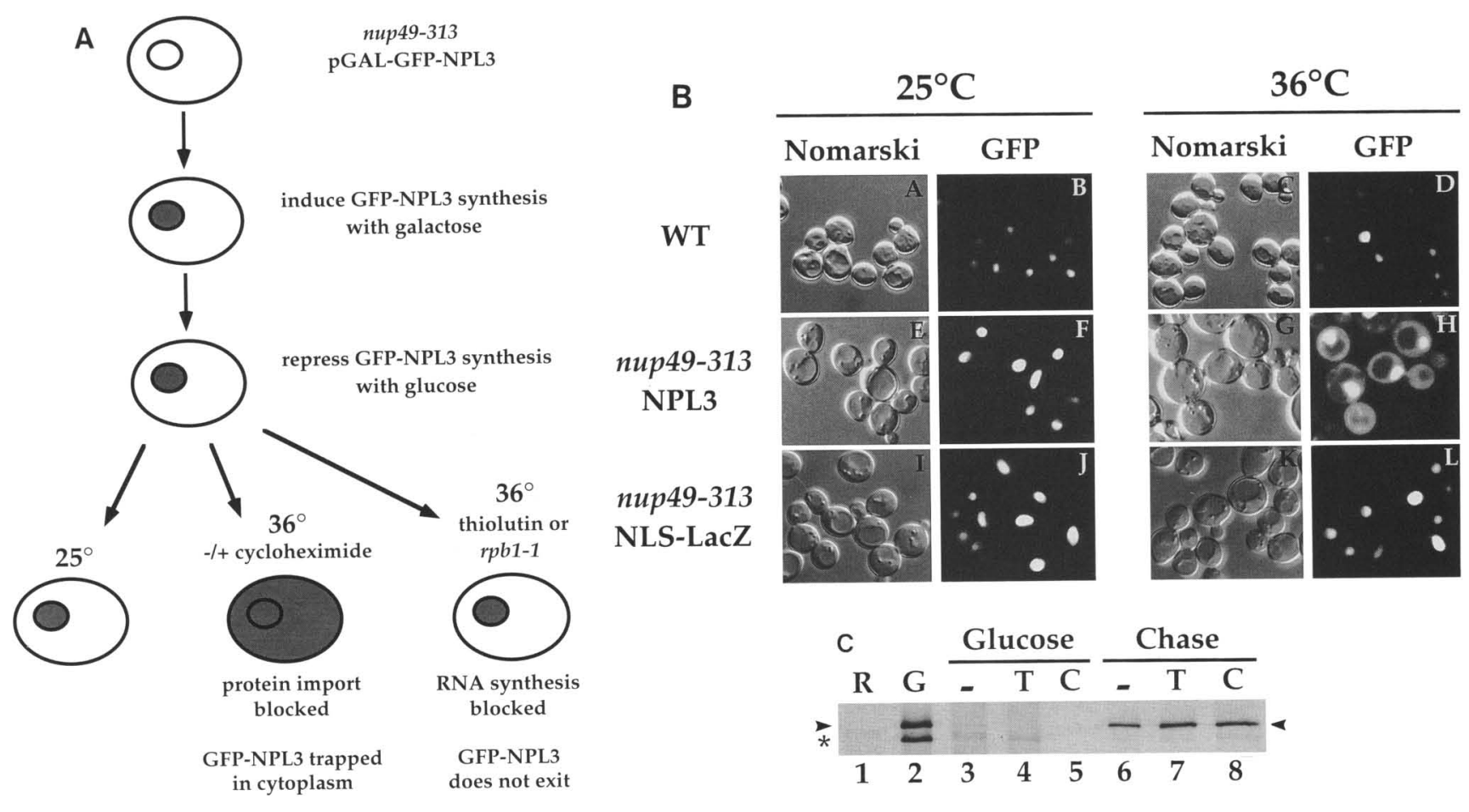

Figure 3. GFP-Npl3 shuttles in the export assay. $(A)$ Schematic diagram of the export assay. $(B)$ Living cells were photographed after incubation in the export assay. Cells were either incubated at $25^{\circ} \mathrm{C}$ (panels $A, B, E, F, I, I$, or at $36^{\circ} \mathrm{C}$ (panels $C, D, G, H, K, L$ ). Cells were photographed either by Nomarski optics (panels $A, C, E, G, I, K$ ) or for GFP fluorescence (panels $B, D, F, H, I, L)$. (Panels $A-D$ ) Wild-type cells expressing GFP-Npl3; (panels $E-H$ ) nup49-313 cells expressing GFP-Npl3; (panels $1-L$ ) nup49-313 cells expressing NLS-GFP-LacZ. $(C)$ nup49-313 cells expressing GFP-Npl3 were grown, radiolabeled, lysed, and immunoprecipitates were prepared as described in Materials and methods. Immune complexes were analyzed by SDS-PAGE and autoradiography. Cells were labeled either in medium containing raffinose (lane 1), galactose (lanes 2,6-81, or after induction in galactose followed by a 2-hr chase in glucose (lanes 3-5). Cells in lanes 1-5 were washed and frozen immediately after labeling; cells in lanes 6-8 were incubated further (chased) in medium containing glucose for another $2 \mathrm{hr}$ at $25^{\circ} \mathrm{C}$, then $5 \mathrm{hr}$ at $37^{\circ}$ as described for the export assay. In addition, cells were incubated with thiolutin (lanes 4,7) or cycloheximide (lanes 5,8) during the 2-hr chase (lanes 4,5) or during the 7-hr chase (lanes 7,81 . The arrowhead indicates full-length GFP-Npl3, the asterisk indicates a short-lived degradation product of GFP-Npl3.

incubated at $36^{\circ} \mathrm{C}$, shuttling proteins should exit the nucleus but should not be reimported, resulting in an accumulation of proteins in the cytoplasm. Therefore, in this assay, the appearance of protein in the cytoplasm is an indicator of protein export.

To visually monitor export, we used a fusion of the green fluorescent protein (GFP) to full-length Npl3p (GFP-Npl3). Expression of this fusion protein was controlled by the inducible GAL1 promoter. GFP-Npl3 was produced in nup 49-313 cells by grow th in galactose-containing medium, after which, the synthesis of the reporter was completely repressed by incubation in medium-containing glucose as a carbon source. If these cells are then incubated at the permissive temperature of $25^{\circ} \mathrm{C}$, the GFP-Npl3 remains entirely nuclear (Fig. 3B, panel $\mathrm{F} \mid$, presumably as a result of the re-uptake of GFPNpl3 into the nucleus from the cytoplasm. When the same cells are incubated at the nonpermissive temperature of $36^{\circ} \mathrm{C}$, the GFP-Npl3 signal accumulates in the cytoplasm of the cell (Fig. 3B, panel $\mathrm{H}$ ) indicating that it is capable of nuclear export. This result is completely dependent on the nup49-313 mutation, because the
GFP-Npl3 reporter remains nuclear at both temperatures in wild-type cells (Fig. 3B, panels B and D). The same results were obtained with a temperature-sensitive nuclear import mutant in a different nucleoporin, $n s p 1$ (data not shown).

Typically, after $5 \mathrm{hr}$ at $36^{\circ} \mathrm{C}, 30 \%-35 \%$ of the cells examined showed a strong GFP signal in the cytoplasm (Fig. 4D, large arrowhead) and an additional 30\%-35\% displayed a weaker but distinctly cytoplasmic GFP signal (Fig. 4D, small arrowhead). In some cells, a bright nuclear GFP-Npl3 signal was also still visible. Many factors could contribute to this remaining nuclear signal. First, the extended time $(5 \mathrm{hr})$ required for the nuclear import defect to occur in nup 49 cells after a shift to the nonpermissive temperature (Schlenstedt et al. 1993; Doye et al. 1994/ could prevent the complete accumulation of GFP-Npl3 in the cytoplasm at the time cells are examined. In addition, when GFP-Npl3 is expressed by the GAL1 promoter, the level of recombinant protein is significantly greater than that of endogenous Npl3p. Therefore, this remaining nuclear signal likely results from excess GFP-Npl3 in the nucleus that may compete 
Lee et al.

Figure 4. GFP-Np13-F160L is not exported from the nucleus. nup49-313 cells expressing GFP-Npl3 $(A-D)$ or GFP-Npl3-F160L $(E-H)$ were processed as described for the export assay and incubated at either $25^{\circ} \mathrm{C}(A, B, E, F)$ or at $36^{\circ} \mathrm{C}(C, D, G, H)$. Living cells were either photographed with Nomarski optics $(A, E, C, G)$ or examined for GFP fluorescence $(B, D, F, H)$.

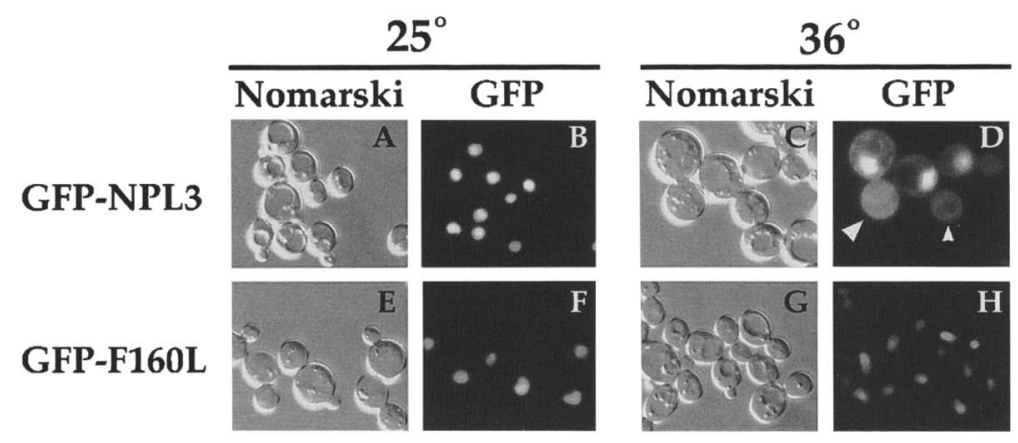

with endogenous Npl3p for saturable components of the export machinery. This remaining nuclear signal is not caused by an export defect in these cells resulting from overexpression of the GFP-Npl3 protein. Although overexpression results in accumulation of poly $(\mathrm{A})^{+}$RNA in the nucleus immediately after induction /data not shown; L. Gorsch and C. Cole, unpubl.), at the time when cells are examined for export lafter repression of GFP-Npl3 synthesis and shift to $36^{\circ} \mathrm{C}$ ), there is no RNA export defect (data not shown).

In contrast to the observed export of GFP-Npl3, a different nuclear protein consisting of the SV40 large T antigen NLS fused to GFP- $\beta$-galactosidase (NLS-GFPLacZ) remains entirely nuclear at both temperatures when examined by use of this assay (Fig. 3B, panels J and L). This result indicates that this NLS-bearing protein can enter the nucleus but is unable to exit once it is there. This result is in agreement with a recently published study (Michael et al. 1995; see Discussion). The continued nuclear localization of NLS-GFP-LacZ also suggests that the appearance of GFP-Npl3 protein in the cytoplasm is not the result of leaky nuclear envelopes.

Because nuclear protein import is blocked in nup49. 313 cells, the accumulation of GFP signal in the cytoplasm must be caused by the export of GFP-Npl3. To confirm this hypothesis further, a pulse-chase experiment was designed to examine the production and stability of GFP-Npl3 during the course of the export assay (Fig. $3 \mathrm{C}$ ). The appearance of the cytoplasmic signal does not result from synthesis of new GFP-Npl3 because such synthesis is completely blocked in the presence of glucose (Fig. 3C, lane 3). In addition, the fusion protein remains stable throughout the incubation period of the experiment (Fig. 3C, lane 6); therefore, this cytoplasmic accumulation of GFP signal does not result from cleavage of the GFP moiety from the Npl3p.

\section{A mutation in the RRM impairs Npl3p nuclear export}

Several of the mutants generated in this study encode amino acid changes in the RRMs of Npl3p (Fig. 2). In addition, a subset of these mutants shows some cytoplasmic localization of Npl3p at permissive temperatures; however, this subset shows only nuclear localization of the protein at the nonpermissive temperature (Table 1). One possible explanation for this aberrant
Npl3p localization is that at the permissive temperature, the import of Npl3p in these mutants is slowed, resulting in its appearance in the cytoplasm, but at the nonpermissive temperature, Npl3p export from the nucleus is blocked, resulting in nuclear accumulation. We therefore hypothesized that $n p 13$ mutants with substitutions in the RRMs may be defective in Npl3p nuclear protein export. To test this idea, we examined the behavior of an Npl3p mutant containing a substitution in RRMl and found it to be defective in export from the nucleus.

The reporter construct used for this analysis was a fusion of GFP with Npl3p in which phenylalanine 160 of Npl3p is changed to leucine (GFP-Npl3-F160L). This substitution was originally identified as one of the mutations in npl3-17 and is located in RRM1 (Fig. 2). When produced in wild-type cells under the regimen used for the shuttling assay, the GFP-Npl3-F160L fusion protein remains localized entirely to the nucleus (data not shown). The localization of this fusion protein was then examined in the nup49-313 protein export assay. As seen in Figure 4, although the GFP-Npl3 accumulates in the cytoplasm of nup $49-313$ cells at $36^{\circ} \mathrm{C}$ (Fig. $4 \mathrm{D}$ ), the GFP-Npl3-F160L mutant remains in the nucleus at this temperature (Fig. $4 \mathrm{H}$ ). These results show that a mutation in RRMl of Npl3p can result in defective export of Npl3p from the nucleus.

\section{RNA synthesis and nuclear protein export}

If Npl3p is participating in RNA export, we might expect the export of Npl3p to be coupled to the presence of mRNA in the nucleus. To explore this possibility, we examined the effect of RNA synthesis on GFP-Npl3 nuclear export.

The antifungal agent thiolutin is an inhibitor of all three RNA polymerases in yeast (Tipper 1973). When the export assay is performed in the presence of thiolutin, GFP-Npl3 does not accumulate in the cytoplasm but, instead, remains in the nucleus of the nup49-313 cells (Fig. 5J). This block in GFP-Npl3 export is not a result of a lack of new protein synthesis because GFP-Npl3 accumulates in the cytoplasm to the same extent when the export assay is performed in the presence (Fig. $5 \mathrm{~L}$ ) or absence (Fig. $5 \mathrm{H}$ ) of the protein synthesis inhibitor cycloheximide. In the nuclei of cells treated with cycloheximide the GFP-Npl3 signal appears to fill a larger 

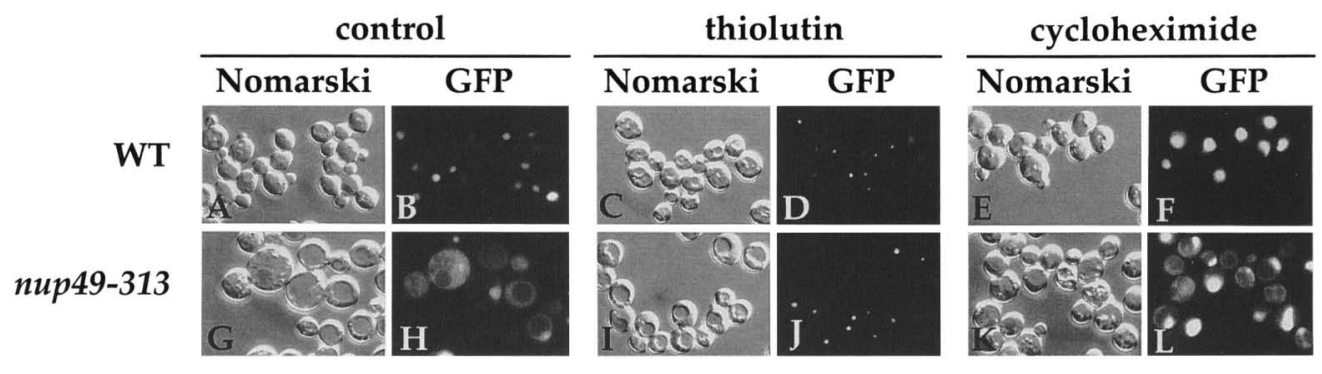

Figure 5. GFP-Npl3 export is dependent on new RNA synthesis. Wild-type $(A-F)$, or nup49-313 $(G-L)$ cells expressing GFP-Npl3 were processed as described for the export assay. Cells were incubated at $36^{\circ} \mathrm{C}$ in the presence of no addition (control, $\left.A, B, G, H\right)$ or in the presence of thiolutin $(C, D, I, J)$ or cycloheximide $(E, F, K, L)$. Living cells were either photographed with Nomarski optics $(A, C, E, G, I, K)$ or examined for GFP fluorescence $(B, D, F, H, I, L)$.

area than it does in the absence of the drug (Fig. $5 F, L)$. Because incubation of nup49-313 cells with cycloheximide results in a more rapid cessation in cellular division than does shift to $36^{\circ} \mathrm{C}$, the relative amount of GFP signal per nucleus in cycloheximide-treated cells is greater than that in untreated cells. Therefore, this apparent increase in size does not result from larger nuclei but, instead, from a much brighter GFP-Npl3 signal in these cells.

The inhibition of only poly $(\mathrm{A})^{+}$RNA synthesis in yeast can also be accomplished by use of a strain that contains a temperature-sensitive allele of RNA polymerase II, rpb1-1 (Nonet et al. 1987). When the export assay is performed with a strain containing both the $r p b 1-1$ and nup49-313 mutations, there is no accumulation of GFP-Npl3 in the cytoplasm (Fig. 6H). These results indicate that the synthesis of poly $(A)^{+}$RNA by RNA polymerase II is required for the export of Npl3p from the nucleus. Together, the two experimental results indicate that new RNA synthesis, and in particular, RNA polymerase II transcription, is absolutely required for the export of Npl3p from the nucleus.

\section{$N p 13 p$ colocalizes with nucleolar antigens in the absence of RNA synthesis}

During the course of these studies, we observed that in the absence of RNA synthesis, the intranuclear distribution of the GFP-Npl3 signal was different from its normal wild-type distribution (Fig. 6, cf. B and F with D and $\mathrm{H}$; Fig. 5, cf. D and J with B). In the absence of RNA synthesis, the Npl3p signal appears condensed into one or two small points within the nucleus. In many yeast mutants blocked in mRNA export, and in the absence of RNA polymerase I (Pol I) transcription, the nucleolus appears fragmented as assayed by immunofluorescence with antibodies to nucleolar antigens (Oakes et al. 1993; Kadowaki et al. 1994a,b,c). Therefore, we wondered whether the intranuclear localization of $\mathrm{Npl} 3 \mathrm{p}$, when export is blocked, coincided with the redistribution of nucleolar proteins.

Cells producing GFP-Npl3 were treated with thiolutin and prepared for immunofluorescence microscopy (Fig. $7 \mathrm{~A}$. To detect nucleolar antigens, we used the monoclonal antibody $9 \mathrm{C} 4$, which reacts with a $32-\mathrm{kD}$ nucleolar protein (Bossie et al. 1992; Loeb et al. 1995). In wild-type cells expressing GFP-Npl3, the GFP signal is distributed throughout the nucleoplasm (panel C), and the nucleolus stains as a crescent-shaped body to one side of the nucleus (panel D). In cells treated with thiolutin, however, the GFP-Npl3 signal is found in a small structure within the nucleus (panel G) that colocalizes with similar structures stained by the 9C4 antibody (panel H). To ensure that the appearance of these structures does not result from the presence of recombinant GFP-Npl3 in the nucleus, we examined endogenous $\mathrm{Npl3p}$ and nucleolar staining in rpb1-1 cells (Fig. 7B). In rpb1-1 cells at $25^{\circ} \mathrm{C}$, endogenous $\mathrm{Npl} 3 \mathrm{p}$ is located throughout the nucleoplasm, and the nucleolus has its characteristic crescent shape (panels $\mathrm{C}$ and $\mathrm{D}$, respectively). In rpb1-1 cells incubated at $36^{\circ} \mathrm{C}$ for as little as $30 \mathrm{~min}$, however, the endogenous Npl3p is again found in a condensed spot in
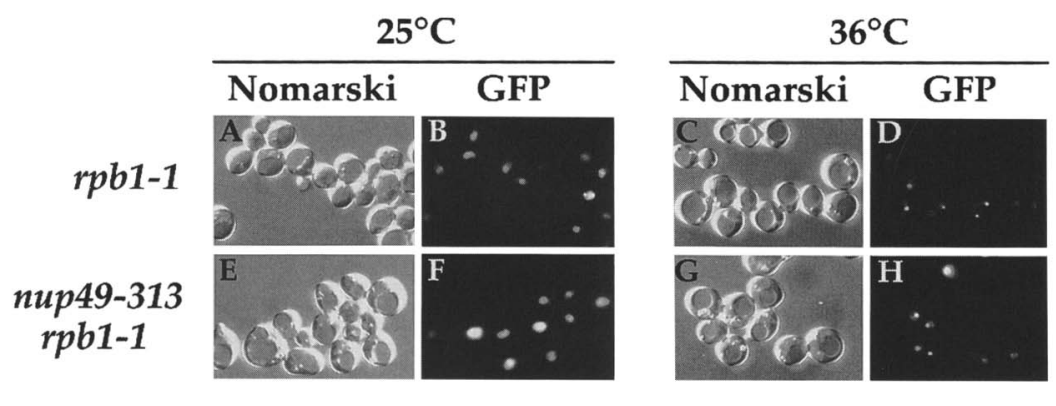

Figure 6. GFP-Npl3 export is dependent on RNA Pol II transcription. rpb1-1 cells $(A-D)$ or nup49-313 rpb1-1 double mutants $(E-H)$ expressing GFP-Npl3 were processed as described for the export assay. Cells were incubated at either $25^{\circ} \mathrm{C}(A, B, E, F)$ or $36^{\circ} \mathrm{C}(C, D, G, H)$. Living cells were either photographed with Nomarski optics $(A, C, E, G)$ or examined for GFP fluorescence $(B, D, F, H)$. 
Lee et al.
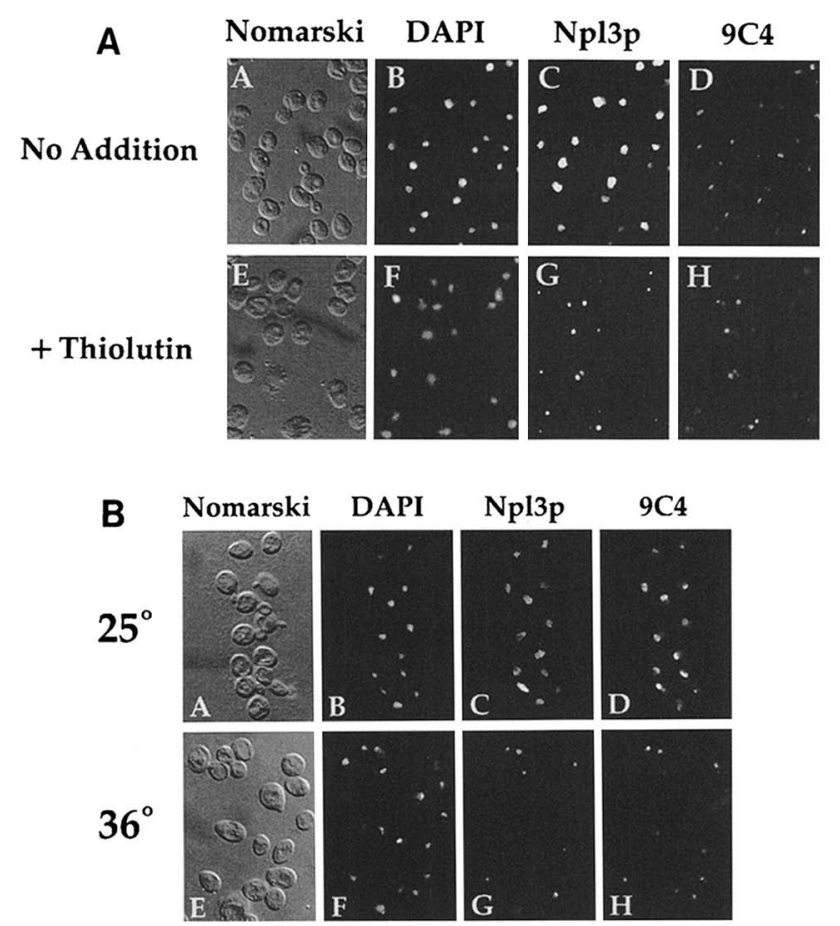

Figure 7. Npl3p colocalizes with nucleolar antigens in the absence of RNA synthesis. (A) Wild-type cells containing the GFP-Npl3 expression plasmid pPS811 were grown and induced as described for the export assay. After induction, GFP-Npl3 synthesis was repressed by growth in YPD for $2 \mathrm{hr}$ in the presence (panels $E-H$ ) or absence (panels $A-D$ ) of thiolutin. Cells were then fixed and processed as described for immunofluorescence. Cells were photographed by use of Nomarski optics (panels $A, E$ ) or DNA was stained with DAPI (panels $B, F$ ). Npl3p was visualized by the GFP signal (panels $C, G$ ), and nucleolar antigens were visualized by use of the $9 \mathrm{C} 4$ monoclonal antibody (panels $D, H) .(B) \mathrm{rpb1}-1$ cells were grown to $1 \times 10^{7} \mathrm{cells} / \mathrm{ml}$ in YPD and incubated at either $25^{\circ} \mathrm{C}$ (panels $A-D$ ) or shifted to $36^{\circ} \mathrm{C}$ for $30 \mathrm{~min}$ (panels $E-H$ ). Cells were fixed and processed as described for immunofluorescence. Cells were photographed by use of Nomarski optics (panels $A, E$ ) or DNA was stained with DAPI (panels $B, F$ ). Npl3p was visualized with anti-Npl3 antisera (panels $C, G$ ), and nucleolar antigens were visualized with the $9 \mathrm{C} 4$ monoclonal antibody (panels $D, H$ ).

the nucleus (panel G) that colocalizes with nucleolar proteins (panel $\mathrm{H}$ ).

\section{Discussion}

Our examination of the yeast RNA-binding protein Npl3p has led to the proposal that the processes of Npl3p and poly $(\mathrm{A})^{+}$RNA export from the nucleus are tightly coupled. We isolated mutations in the two RRMs of Npl3p that result in defects in export of poly $\mid \mathrm{A})^{+} \mathrm{RNA}$ from the nucleus. To establish a link between the processes of protein and poly $(\mathrm{A})^{+}$RNA, we developed a new system to study the export of Npl3p from the nucleus. Using this assay, we have shown that a mutation in one of the RNA-binding domains of Npl3p results in a block in Npl3p export from the nucleus. Furthermore, the export of Npl3p from the nucleus is dependent on the RNA synthesis by RNA polymerase II. We propose a model in which Npl3p acts as a carrier for poly $(A)^{+}$RNA export from the nucleus.

\section{A new assay for nuclear protein export}

We have developed an assay system to examine the export of proteins from the yeast nucleus. This assay is based on the properties of yeast temperature-sensitive nucleoporin mutants that are defective in nuclear protein import at the nonpermissive temperature. In nup49 and $n s p 1$ mutant cells, export is scored as accumulation of the reporter protein in the cytoplasm at the nonpermissive temperature. A previous test for nuclear protein shuttling relied on the production of heterokaryons (Flach et al. 1994). Our system has advantages over the use of heterokaryons; in particular, it allows us to uncouple nuclear protein export from reimport.

The yeast heterokaryon experiments were based on the fact that yeast karyogamy mutants are defective in nuclear fusion after mating (Flach et al. 1994). When a heterokaryon is formed, the two cells exchange cytoplasms, resulting in a rescue of any defects not shared by both cells, thereby preventing the use of yeast mutants to examine the process of export. Because the assay presented here does not rely on the mating of yeast cells, it can be performed in the presence of drugs and mutations that otherwise block cellular processes required for mating.

The search for a specific signal for protein export from the nucleus has led to differing conclusions about the requirements for this process. The retention of nuclear proteins by interaction with nuclear structures or chromatin is likely to counteract the passive diffusion of proteins out of the nucleus (Schmidt-Zachermann et al. 1993|. Nuclear export signals (NESs), however, can drive the rapid and active export of proteins from the nucleus (Fischer et al. 1995; Michael et al. 1995; Wen et al. 1995). Here we report that an artificial nuclear protein containing a classic NLS does not exit the nucleus. This result, along with similar recently published data (Michael et al. 1995), is in conflict with the previous suggestion that a classic NLS can promote the efflux of protein from the nucleus (Guiochon-Mantel et al. 1994). We believe, however, that our export assay is a more faithful representation of the in vivo situation where proteins are targeted into the nucleus by their NLS and exit only if they contain export signals or interact with another normally exported protein.

\section{Npl3p mutants affect transport of RNA out of the nucleus}

One temperature-sensitive allele, npl3-1, has been shown previously to accumulate mRNA abnormally in the nucleus at the nonpermissive temperature (Singleton et al. 1995; Henry et al. 1996). This result suggests that 
Npl3p might somehow be involved in export of mRNA from the nucleus. Moreover, Npl3p is a major poly $\mid A)^{+}$ RNA-binding protein that shuttles between the nucleus and the cytoplasm. We now present several lines of evidence to support the hypothesis that Npl3p and poly $(\mathrm{A})^{+}$ RNA export are tightly coupled processes and that Npl3p is a mediator of RNA export.

First, mutations in the RRMs of Npl3p result in defective poly $\mid \mathrm{A})^{+}$RNA export. Six of the seven temperaturesensitive mutants generated in this study contain one or more mutations within the two RRMs of Npl3p. All of these mutants display nuclear localization of $\mathrm{Npl3p}$, and accumulation of poly $(\mathrm{A})^{+} \mathrm{RNA}$ in the nucleus at the nonpermissive temperature indicating a defect in RNA export. At face value, these results are difficult to interpret because the immunofluorescence localization reflects only the steady-state distribution of Npl3p. It is only when we employ the export assay, which measures the dynamics of Npl3p, that we can get a clearer picture of what is happening. Then we find that one of the mutations in a highly conserved amino acid in the RRM results in defective export of Npl3p from the nucleus. Moreover, by two different approaches we show that the export of Npl3p is dependent on the synthesis of new RNA. One approach utilizes the drug thiolutin to block synthesis of all RNA, whereas the other uses the rpb1-1 temperature-sensitive mutant to specifically block RNA polymerase II (Pol II) transcription. Under both of these circumstances, Npl3p does not exit the nucleus. Together, these results indicate that $\mathrm{Npl} 3 \mathrm{p}$ and poly $(\mathrm{A})^{+}$ RNA each require the presence of the other for proper export from the nucleus.

A model incorporating these results is presented in Figure 8. We propose that Npl3p (and other RNA-binding proteins) forms a complex with poly(A) ${ }^{+}$RNA in the nucleus, and at some point this complex becomes competent for export. Once in the cytoplasm, the complex would dissociate and Npl3p would be reimported for an-

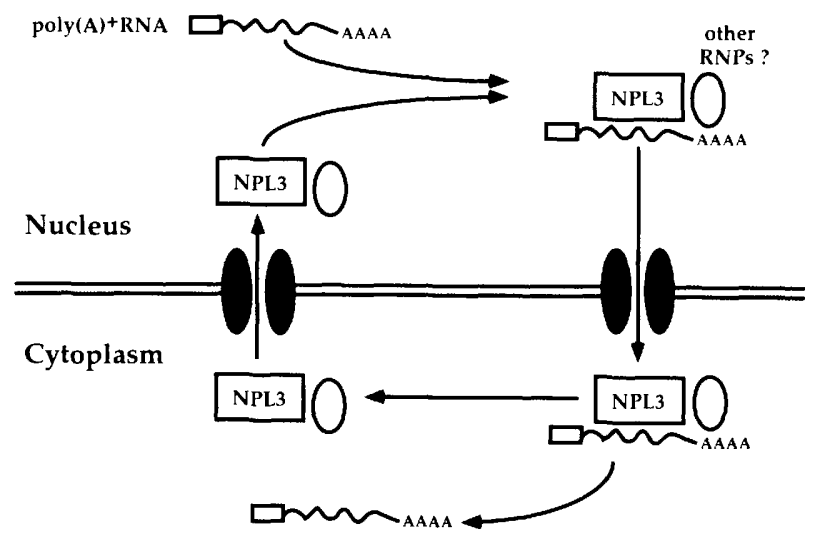

Figure 8. Model for Npl3p transport. Npl3p forms a complex with poly $(A)^{+}$RNA in the nucleus. This complex is then exported to the cytoplasm via the nuclear pore complex. Once in the cytoplasm, the complex dissociates and $\mathrm{Npl} 3 \mathrm{p}$ is reimported for another round of RNA-binding and export. other round of RNA binding and export. Our results suggest that mutations in the RRMs of Npl3 block RNA binding or prevent binding of RNA in the proper conformation, resulting in a complex that is not competent for export. In this case, both Npl3p and poly $(\mathrm{A})^{+}$RNA remain in the nucleus. Our results also suggest that if RNA synthesis is blocked, the RNA-Npl3p complex would never form, resulting in an inability of Npl3p to exit the nucleus.

One of the mutants generated in this study, npl3-27, does not display any defect in poly $\mid \mathrm{A})^{+}$RNA export, and the steady-state distribution of the mutant Npl3p in these cells is predominantly cytoplasmic. How can these results be reconciled with a model in which Npl3p is required for poly $(\mathrm{A})^{+}$RNA export? One possibility is that although the npl3-27 mutant protein appears mostly cytoplasmic, enough of this protein is able to enter the nucleus to support poly $(\mathrm{A})^{+}$RNA export, as a result of either a reduced rate of nuclear import or a defect in retention of the mutant Npl3p within the nucleus. By the latter scenario, premature export of the mutant Npl3p-RNA complex could result in the temperature-sensitive growth defect in npl3-27 cells. These possibilities are supported by two separate observations: First, the mutant Npl3p does not appear to be excluded from the nucleus in npl3-27 cells, and second, npl3-27 mutant protein accumulates in the nucleus in a strain that is also defective in poly $(\mathrm{A})^{+}$RNA export (data not shown). Alternatively, the npl3-27 defect may result in a bypass in the requirement for $\mathrm{Npl3p}$ in poly $(\mathrm{A})^{+} \mathrm{RNA}$ export. In this event, the npl3-27 protein must play some essential role independent of poly $(A)^{+}$RNA export, which results in the temperature-sensitive growth defect.

Although the majority of the mutants analyzed display accumulation of poly $(\mathrm{A})^{+}$RNA in the nucleus, the presence of a cytoplasmic RNA signal indicates that in no case is there a complete block in export. This may be explained in part by the fact that Npl3p is an extremely stable protein. When the synthesis of Npl3p is repressed in a strain where the GAL1 promotor controls its expression, the protein is still present after $18 \mathrm{hr}$ of growth in a glucose-containing medium (Russell and Tollervey 1992), and poly(A) ${ }^{+}$RNA export still appears normal at this time (M. Henry and P. Silver, unpubl.). In addition, although the expression of GFP-Npl3 controlled by the GAL1 promoter has ceased completely after $2 \mathrm{hr}$ of growth in a glucose-containing medium, the protein persists for at least $5 \mathrm{hr}$ more in nup49-313 cells (Fig. 3C). If Npl3p is present in a stable hnRNP complex, this could explain its long half-life in the absence of expression. A stable hnRNP complex could partially protect the heat labile mutants used in this study and result in the leaky RNA export phenotype that we have observed.

What targets the Npl3p-RNA complex for export from the nucleus? Npl3p does not contain amino acid sequences similar to the NESs identified previously in Rev, PKI, and hnRNP Al (Fischer et al. 1995; Michael et al. 1995; Wen et al. 1995). The heterogeneity of export signals identified to date, however, indicates the possibility 
that additional types of export sequences exist. A mutation in the RRM of Npl3p blocks its efficient export from the nucleus, suggesting that sequences within this domain have a role in targeting Npl3p for export. It is also possible that correct association of the RNA-Npl3p complex results in the appearance of an export signal. It is not known whether RNA is required for the export of Rev or hnRNP Al, although the NESs identified in these proteins lie outside of their RNA-binding domains. A final possibility is that the interaction between Npl3p and poly $(\mathrm{A})^{+}$RNA results in association of this complex with an unidentified NES-containing protein capable of targeting the Npl3p-RNA complex for export.

\section{Similarities and differences with hnRNP A1 protein}

Like Npl3p, hnRNP Al protein is an RNA-binding protein that shuttles between the nucleus and the cytoplasm in mammalian cells (Piñol-Roma and Dreyfuss 1992, 1993). The hnRNP Al protein has also been proposed to act as a carrier for poly $\mid \mathrm{A})^{+}$RNA export from the nucleus (Piñol-Roma and Dreyfuss 1991, 1992). hnRNP Al contains two tandemly arranged RRMs and a carboxy-terminal glycine-rich domain (for review, see Dreyfuss et al. 1993). Also, like many other RNA-binding proteins, hnRNP Al contains an RGG box domain that confers full RNA-binding capacity (Biamonti and Riva 1994). A 39-amino-acid nuclear import signal has been identified in the glycine-rich carboxyl terminus of human hnRNP Al (Siomi and Dreyfuss 1995; Weighardt et al. 1995). This signal, termed M9, also functions as an NES (Michael et al. 1995).

There are noteworthy parallels between hnRNP Al and Npl3p. They share a significant degree of structural similarity. Neither contains prototypical NLSs, and Npl3p does not contain a sequence similar to the NLS defined by hnRNP Al. Like hnRNP Al, however, sequences required for proper nuclear targeting of Npl3p lie within its glycine-rich carboxyl terminus. Removal of the carboxy-terminal RGG box domain from Npl3p results in cytoplasmic localization of the protein (Flach et al. 1994). Also, in the npl3-27 mutant, a substitution in the extreme carboxyl terminus of Npl3p results in cytoplasmic accumulation.

Our findings also indicate that the dynamics of Npl3p and hnRNP Al localization differ significantly in their dependence on the new synthesis of RNA. We show that the nuclear export of Npl3p requires the synthesis of Pol II transcripts, which is what one might expect for an RNA carrier protein. This is not the case for human hnRNP Al. This protein instead requires ongoing Pol II transcription for its proper reimport into the nucleus (Pinol-Roma and Dreyfuss 1991). Our experiments cannot address whether Pol II transcription is required for $\mathrm{Npl} 3 \mathrm{p}$ import because Npl3p does not exit the nucleus in its absence. Therefore, our results illustrate both similarities and differences between Npl3p and hnRNP Al and provide the first example of a shuttling protein whose export is dependent on the new synthesis of RNA.
Mutations in conserved amino acids of Npl3p affect RNA export

When the two RRMs of Npl3p are subjected to alignment with 68 other RRMs from proteins thought to be involved in RNA binding and processing, each of the mutants displaying defects in poly $\mid \mathrm{A})^{+}{ }^{+}$RNA export contains substitutions mapping to residues at or near sites of high conservation. In particular, phenylalanine 160 in Npl3p lies in position 35 of the RRM consensus sequence. This is one of the three solvent-exposed aromatic positions in the RRM consensus that has been implicated in RNA-binding (Birney et al. 1993). In position 35, phenylalanine is present $60 \%$ of the time fof 179 aligned sequences|, although this position can tolerate substitutions in some RRM-containing proteins. Therefore, it is possible that mutation of phenylalanine 160 to leucine disrupts the proper interaction of Npl3p with RNA, and this disruption is responsible for its inability to exit the nucleus. One prospect is that this mutant protein no longer binds RNA, although it is also possible that RNA binds the mutant with a different conformation than it does with the wild-type protein. If the nature of this RNA-Npl3p complex is important for proper export from the nucleus, then either possibility could result in the observed block in export seen for these two species. It is also noteworthy that there appears to be a bias toward recovering temperature-sensitive mutations that correspond to changes in the RRMs-six of seven mutants that we studied fall into this category.

During the course of this study, we observed that in the absence of Pol II transcription, both GFP-Npl3 and endogenous Npl3p appear to accumulate in a discrete location in the nucleus that colocalizes with a nucleolar antigen. This is similar to the mininucleolar bodies in which Npl3p is localized in the absence of Pol I transcription (Russell and Tollervey 1992; Oakes et al. 1993). Some have suggested that RNA may transit through the nucleolus on its way out of the nucleus (Kadowaki et al. 1994b, 1995; Tani et al. 1995). By this scenario, Npl3p would be trapped at this intermediate stage in the absence of poly $(A)^{+}$RNA. Alternatively, in the absence of poly $\mid \mathrm{A})^{+}$RNAs, Npl3p could associate with RNAs in the nucleolus, or the nucleolus may act as a repository for proteins involved in RNA processing and trafficking.

\section{Conclusions}

In sum, we have demonstrated a link between the nuclear export of poly $\mid \mathrm{A})^{+}$RNA and that of a shuttling RNA-binding protein. These results support a model in which $\mathrm{Npl} 3 \mathrm{p}$ functions as a carrier for poly $(\mathrm{A})^{+} \mathrm{RNA}$ out of the nucleus. The study of the process of molecular export from the nucleus has provided a greater understanding of the processes of protein and RNA export. Our results provide a connection between these two rapidly growing fields of study. 


\section{Materials and methods}

Plasmid constructs

The plasmid constructs used in this study are listed in Table 2. Unless otherwise stated, all PCR amplifications were performed with Pfu DNA polymerase (Stratagene). A 1.5 -kb insert containing the entire NPL3 gene was generated by PCR amplification, digested with $B a m H I$, and ligated into BamHI-linearized pBluescript (Stratagene) to create pPS425. A fusion of GFP to the amino terminus of Npl3p (pPS811) was created by ligation of the $1.5-\mathrm{kb} B a m H I$ fragment from pPS425 into BamHI-linearized pCGF-1A (Kahana and Silver 1996). To create pPS817, a BamHI-SphI fragment from pPS815 (a gift from Jim Haseloff, Medical Research Council, Cambridge, UK), containing the SV40 T-antigen NLS fused to a GFP- $\beta$-galactosidase fusion protein, was ligated into BamHI/SphI-linearized pPS293, a highcopy, YEp352-based vector containing the GAL1/10 promoter (Yocum et al. 1984) and a polylinker sequence. The plasmid pPS877 was created by ligation of a $4.5-\mathrm{kb}$ ClaI fragment from the original plasmid pPS870 containing npl3-17 into ClaI-linearized pRS306 (Sikorski and Hieter 1989). pPS879 was created by ligation of a 278-bp Bglll fragment from pPS877 into BglIIlinearized pPS811. The plasmid pMHY11 was constructed in two steps as follows. First, the complete NPL3 gene as a $3.5 \mathrm{~kb}$ Scal fragment was inserted into the SmaI site of YEp352 to yield pMHY7. The complete NPL3 gene was then excised from pMHY7 as a SacI fragment and inserted into pPS709 $\{2 \mu$ ADE 3 $U R A 3)$ to yield pMHY11.

\section{Yeast strains}

Growth and maintenance of yeast strains, as well as all genetic manipulations were performed as described previously (Rose et al. 1990). The strains used in this study are listed in Table 3. MHY 132 contains a disruption of NPL3 in a genetic background in which this gene is essential (Russell and Tollervey 1992;
Table 3. Yeast strains

\begin{tabular}{|c|c|c|}
\hline Strain & Genotype & Source \\
\hline MHY132 & $\begin{array}{l}\text { mata npl3::HIS } 3 \text { ura3-1 lys2 } \\
\text { leu2 ade2 ade3 plus pMHY11 }\end{array}$ & this study \\
\hline nup49-313 & $\begin{array}{l}\text { mata nup } 49: \text { :TRP1 ura3 leu2 } \\
\text { his3 ade2 ade3 plus pUN } 100 \\
\text { nup } 49^{t s}-\text { LEU2 }\end{array}$ & Doye et al. (1994) \\
\hline FY23 & mata ura3.52 leu $2 \Delta 1$ trp $1 \Delta 63$ & F. Winston \\
\hline Y262 & mata rpb1-1 ura 3.52 his 4.539 & Nonet et al. (1987) \\
\hline $\mathrm{CH} 1305$ & $\begin{array}{l}\text { mata ura3 leu2 ade2 ade3 lys2 } \\
\text { can1 }\end{array}$ & $\begin{array}{l}\text { Kranz and Holm } \\
\text { (1990) }\end{array}$ \\
\hline PSY704 & $\begin{array}{l}\text { mata rpb1-1 ura3-52 leu2d1 } \\
\text { his } 4-539\end{array}$ & this study \\
\hline PSY814 & $\begin{array}{l}\text { mata npl3:: HIS3 ura3-52 leu2-3 } \\
\text { his3 trp1-1 ade2-1 lys1-1 } \\
\text { can1-100 plus YCp50-NPL3-3 }\end{array}$ & Henry et al. (1996) \\
\hline PSY844 & $\begin{array}{l}\text { mat } \alpha \text { rpb1-1 nup } 49: \text { TRP1 ura3 } \\
\text { leu2 -ade3his plus pUN } 100 \\
\text { nup } 49^{t s}-\text { LEU2 }\end{array}$ & this study \\
\hline
\end{tabular}

Henry et al. 1996) that is rescued by a plasmid carrying a wildtype copy of NPL3 (pMHY11). This strain was created by the mating of PSY814 with CH1305 (Kranz and Holrn 1990). Diploids were grown on 5-fluoro-orotic acid (FOA), transformed with pMHY11, and sporulated. PSY704 was created by the crossing of Y262 (Nonet et al. 1987) with the wild-type strain FY23 (a gift from Fred Winston, Harvard Medical School, Boston, MA). A double mutant containing both nup49-313 and rpb1-1 was generated by the crossing of PSY704 with nup49313 (Doye et al. 1994).

\section{Generation of temperature-sensitive mutants}

A panel of new temperature-sensitive npl3 mutants was generated by use of a PCR mutagenesis and plasmid shuffling proto-

Table 2. Plasmid constructs

\begin{tabular}{|c|c|c|}
\hline Plasmid & Features & Source \\
\hline pPS293 & yeast high-copy galactose-inducible expression vector $U R A 3$ & $\begin{array}{l}\text { G. Schlenstedt and P. Silver } \\
\text { (unpubl. plasmid) }\end{array}$ \\
\hline pPS425 & PCR-amplified 1.5-kb BamHI fragment of $N P L 3$ in pBluescript & $\begin{array}{l}\text { M. Bossie and P. Silver } \\
\text { (unpubl. plasmid) }\end{array}$ \\
\hline pRS306 & yeast integration vector $U R A 3$ & Sikorski and Hieter (1989) \\
\hline pCGF-1A & $\begin{array}{l}\text { yeast high-copy galactose-inducible expression vector for fusion to the carboxyl } \\
\text { terminus for GFP }\end{array}$ & Kahana and Silver (1996) \\
\hline YEp352 & high-copy yeast shuttle vector $U R A 3$ & Hill et al. (1993) \\
\hline pMHY3 & 3.8-kb chromosomal sequence containing $N P L 3$ in YCp50-LEU2 & Henry et al. (1996) \\
\hline $\begin{array}{r}\text { pMHY3- } \\
\text { npl3-1 }\end{array}$ & $3.8-\mathrm{kb}$ chromosomal sequence containing npl3-1 in YCp50-LEU2 & Henry et al. $\{1996)$ \\
\hline pMHY7 & 3.5-kb ScaI fragment of NPL3 in YEp352 & this study \\
\hline pMHY11 & 3.5-kg SacI fragment containing NPL3 in pPS709 & this study \\
\hline pPS709 & High-copy yeast vector $A D E 3 U R A 3$ & $\begin{array}{l}\text { D. Koepp and P. Silver } \\
\text { (unpubl. plasmid) }\end{array}$ \\
\hline pPS811 & 1.5-kb BamHI fragment from pPS425 containing NPL3 in pCGF-1A & this study \\
\hline pPS815 & $\begin{array}{l}\text { SV } 40 \text { NLS fused to GFP- } \beta \text {-galactosidase fusion in pVT103-U, a high-copy } \\
\text { constitutive yeast expression vector } U R A 3\end{array}$ & $\begin{array}{l}\text { Jim Haselhoff } \\
\text { (unpubl. plasmid) }\end{array}$ \\
\hline pPS817 & $\begin{array}{l}\text { 4.2-kb BamHI-SphI fragment from pPS } 815 \text { containing SV40-GFP- } \beta \text {-galactosidase } \\
\text { in pPS } 293\end{array}$ & this study \\
\hline pPS870 & np13-17 allele gap repaired into pMHY3 & this study \\
\hline pPS877 & 4.5-kb ClaI fragment from pPS 870 in pRS306 & this study \\
\hline pPS879 & 278-bp BglII fragment from pPS877 in pPS811 & this study \\
\hline
\end{tabular}


col. Briefly, a 2492-bp PCR product was generated that contains the entire NPL3 open reading frame by use of TaqI polymerase (Promega) according to the manufacturers' instructions and was purified with a Qiaquick column (Qiagen). The plasmid pMHY3 (Henry et al. 1996) was linearized with NcoI and PmlI, and a repair ligation (Orr-Weaver and Szostak 1983) was achieved by cotransformation of the strain MHY 132 with the PCR product and linear pMHY3. Colonies were selected on synthetic complete medium (SC) lacking leucine, followed by replica plating to $25^{\circ} \mathrm{C}$ and $37^{\circ} \mathrm{C}$ on SC lacking leucine and containing FOA and $7.5 \mathrm{mg} /$ liter of the vital dye erythrocin B. Of 49 strains, 48 remained temperature sensitive after rescue of the plasmid, retransformation into MHY132, and selection on SC lacking leucine and containing FOA. Of these, seven were chosen, and the NPL3 ORF was sequenced entirely by use of a Stratagene sequencing kit. To generate growth curves, strains were inoculated into $10 \mathrm{ml}$ of SC lacking leucine and grown overnight at $25^{\circ} \mathrm{C}$. Cells were counted with a hemacytometer, and cultures diluted to $2 \times 10^{6}$ cells $/ \mathrm{ml}$ in fresh medium. Cell counts were generated every $4 \mathrm{hr}$ thereafter. After $8 \mathrm{hr}$ at $25^{\circ} \mathrm{C}$, each culture was split and shifted to either $30^{\circ} \mathrm{C}$ or $37^{\circ} \mathrm{C}$.

\section{Indirect immunofluorescence}

Indirect immunofluorescence microscopy was performed essentially as described (Bossie et al. 1992), with the following modifications. Cells were spheroplasted with Zymolyase (100T, ICN) at a concentration of $300 \mu \mathrm{g} / \mathrm{ml}$, placed on slides coated with $0.3 \%$ polylysine, and permeablized by addition of $0.5 \%$ NP-40 in solution $\mathrm{P} / 0.1 \mathrm{M} \mathrm{K}_{2} \mathrm{HPO}_{4}-\mathrm{KH}_{2} \mathrm{PO}_{4}$ at $\mathrm{pH} 6.5,1.2 \mathrm{M}$ sorbitol) for $5 \mathrm{~min}$. Cells were washed once with solution $\mathrm{P}$, blocked for $1 \mathrm{hr}$ with antibody blocking buffer $(0.1 \mathrm{M}$ Tris- $\mathrm{HCl}$ at $\mathrm{pH} 9.0,0.15 \mathrm{M} \mathrm{NaCl}, 5 \%$ heat-inactivated fetal calf serum, $0.3 \%$ Triton TX-100), followed by overnight incubation with the primary antibody in antibody blocking buffer. Cells were washed extensively after primary and secondary antibody incubations with buffer $1(0.1 \mathrm{M}$ Tris- $\mathrm{HCl}$ at $\mathrm{pH} 9.0,0.15 \mathrm{M} \mathrm{NaCl})$ and buffer $210.1 \mathrm{M}$ Tris- $\mathrm{HCl}$ at $\mathrm{pH} 9.5,0.1 \mathrm{M} \mathrm{NaCl}, 50 \mathrm{~mm}$ $\mathrm{MgCl}_{2}$ ). Affinity-purified rabbit anti-NPL3 (Bossie et al. 1992) was used at a 1:1000 dilution, mouse monoclonal 9C4 (Flach et al. 1994; Loeb et al. 1995/ was used at a 1:100 dilution, and fluorescein isothiocyanate (FITC) or Texas Red-conjugated secondary antibodies (Jackson) were used at a 1:1000 dilution. Nuclei were stained with $10 \mu \mathrm{g} / \mathrm{ml}$ of 4' 6-diamido-2-phenylindole dihydrochloride (DAPI) for $5 \mathrm{~min}$ in buffer 2, followed by two washes in buffer 2 .

\section{In situ RNA hybridization}

Localization of poly $(\mathrm{A})^{+}$RNA by in situ hybridization was performed essentially as described (Amberg et al. 1992), with some modifications. Cells were fixed, washed, spheroplasted, and permeablized as described for immunofluorescence. After incubation with a digoxigen-labeled oligo $\left[\mathrm{d}\left(\mathrm{T}_{50}\right)\right]$ probe, cells were then processed for immunofluorescence as described above, begin. ning with the antibody blocking buffer step. The Texas Red sheep anti-digoxigen Fab fragment (Boerringer Mannheim) was used at a 1:100 dilution, and rabbit anti-NPL3 at a 1:1000 dilution overnight at $25^{\circ} \mathrm{C}$. An FITC-conjugated anti-rabbit secondary antibody (Jackson) was used at a l:1000 dilution.

\section{Nuclear export assay}

nup49-313 (Doye et al. 1994) cells containing vectors for expression of GFP-fusion proteins were grown at $25^{\circ} \mathrm{C}$ to mid-log phase in SC medium lacking uracil and containing $2 \%$ glucose as a carbon source. Cultures were diluted $1: 200$ into SC medium lacking uracil and containing $2 \%$ raffinose as a carbon source and grown at $25^{\circ} \mathrm{C}$ to a density of $0.5 \times 10^{7}$ to $1 \times 10^{7}$ cells $/ \mathrm{ml}$. GFP fusion proteins were induced by the addition of galactose to a final concentration of $2 \%$. After $2 \mathrm{hr}$ at $25^{\circ} \mathrm{C}$, cells were collected by centrifugation at $2000 \mathrm{~g}$ for $5 \mathrm{~min}$ and resuspended in an equal volume of YPD. This step was repeated, and cells were incubated for $2 \mathrm{hr}$ at $25^{\circ} \mathrm{C}$ in YPD. Cultures $(10 \mathrm{ml})$ were then either shifted to $36^{\circ} \mathrm{C}$ or remained at $25^{\circ} \mathrm{C}$ for an additional $5 \mathrm{hr}$. Cells were then pelleted by centrifugation at $12,000 \mathrm{~g}$ for $1 \mathrm{~min}$ and resuspended in SC lacking uracil. Cells were then examined for GFP fluorescence signal in the FITC channel of an Axioscop fluorescence microscope (Zeiss). Thiolutin was used at a final concentration of $15 \mu \mathrm{g} / \mathrm{ml}$, and cycloheximide at a concentration of $10 \mu \mathrm{g} / \mathrm{ml}$. When used, these drugs were added after the second YPD wash.

\section{Radiolabeling and immunoprecipitation}

nup49-313 cells containing the pPS811 expression plasmid were grown as described for the export assay except that the growth medium lacked methionine. For labeling, cell cultures were pelleted by centrifugation at $2000 \mathrm{~g}$ for $5 \mathrm{~min}$, and all but $500 \mu \mathrm{l}$ of medium was aspirated. Cells were resuspended in the remaining medium and $150 \mu \mathrm{Ci}(15 \mu \mathrm{l})$ of $\operatorname{EXPRE}^{35} \mathrm{~S}^{35}$ S Protein Labeling Mix (>1000 Ci/mmole, NEN) was added, and labeling was allowed to proceed for $15 \mathrm{~min}$ at room temperature. Cells were pelleted by centrifugation at $12,000 \mathrm{~g}$ for $1 \mathrm{~min}$ and washed twice with ice-cold water. Cell pellets were frozen at $-20^{\circ} \mathrm{C}$. For samples that were chased after labeling, cells were washed twice in YPD, resuspended in the original volume of YPD, and carried through the rest of the export assay. For immunoprecipitation, frozen cell pellets were resuspended in $50 \mu \mathrm{l}$ of lysis buffer $(50 \mathrm{~mm}$ Tris- $\mathrm{HCl}$ at $\mathrm{pH} 7.5,100 \mathrm{~mm} \mathrm{NaCl}, 5 \mathrm{~mm}$ EDTA $1 \%$ Triton $\mathrm{X}-100)$ supplemented with protease inhibitors $\langle 0.5$ $\mathrm{mM}$ PMSF and $3 \mu \mathrm{g} / \mathrm{ml}$ each of pepstatin, leupeptin, aprotinin, and chymostatin). Glass beads $(5 \mathrm{mg}, 0.5 \mathrm{~mm})$ were added, and the cells were lysed by repeated vortexing at $4^{\circ} \mathrm{C}(3 \times$ for $30 \mathrm{sec}$ each). Lysates were clarified by centrifugation for $10 \mathrm{~min}$ at $12,000 \mathrm{~g}$ at $4^{\circ} \mathrm{C}$. Lysates were incubated with $5 \mu \mathrm{l}$ of rabbit anti$\mathrm{Npl3p}$ antiserum for $2 \mathrm{hr}$ at $4^{\circ} \mathrm{C}$ with rocking. $\mathrm{Npl3p}$-antibody complexes were precipitated by addition of $100 \mu \mathrm{l}$ of a $50 \%$ slurry of protein A-Sepharose (Pharmacia) and incubation for 1 hr with rocking at $4^{\circ} \mathrm{C}$. Beads were washed three times with lysis buffer, and immunoprecipitated proteins were visualized by separation on a $10 \%$ SDS-polyacrylamide gel followed by autoradiography.

\section{Acknowledgments}

We thank our colleagues Chuck Stiles, Tom Rapoport, Chuck Cole, David Pellman, and members of our laboratory for their insightful comments on the manuscript and Rick Young, Valerie Doye, Ed Hurt, and Jim Haselhoff for strains and plasmids. This work was supported by grants from the National Institutes of Health to P.A.S. M.S.L. and M.H. were supported by postdoctoral fellowships from the American Cancer Society.

The publication costs of this article were defrayed in part by payment of page charges. This article must therefore be hereby marked "advertisement" in accordance with 18 USC section 1734 solely to indicate this fact.

\section{References}

Amberg, D.C., A.L. Goldstein, and C.N. Cole. 1992. Isolation and characterization of an essential gene of Saccharomyces 
cerevisiae required for the efficient nucleocytoplasmic trafficking of mRNA. Genes \& Dev. 6: 1173-1189.

Anderson, J.T., S.M. Wilson, K.V. Datar, and M.S. Swanson. 1993. NAB2: A yeast nuclear polyadenylated RNA-binding protein essential for cell viability. Mol. Cell. Biol. 13: 27302741.

Bandziulis, R.J., M.S. Swanson, and G. Dreyfuss. 1989. RNAbinding proteins as developmental regulators. Genes \& Dev. 3: $431-437$.

Bataille, N., T. Helser, and H.M. Fried. 1990. Cytoplasmic transport of ribosomal subunits microinjected into the Xenopus laevis oocyte nucleus. J. Cell Biol. 111: 1571-1582.

Biamonti, G. and S. Riva. 1994. New insights into the auxiliary domains of eukaryotic RNA binding proteins. FEBS Lett. 340: $1-8$.

Birney, E., S. Kumar, and A.R. Krainer. 1993. Analysis of the RNA-recognition motif and RS and RGG domains: Conservation in metazoan pre-mRNA splicing factors. Nucleic Acids Res. 21: 5803-5816.

Bossie, M.A., C. DeHoratius, G. Barcelo, and P.A. Silver. 1992. A mutant nuclear protein with similarity to RNA-binding proteins interferes with nuclear import in yeast. Mol. Biol. Cell 3: 875-893.

Dargemont, C. and L.C. Kuhn. 1992. Export of mRNA from microinjected nuclei of Xenopus laevis oocytes. I. Cell Biol. 118: 1-9.

Doye, V., R. Wepf, and E.C. Hurt. 1994. A novel nuclear pore protein Nup133p with distinct roles in poly $(A)^{+}$RNA transport and nuclear pore distribution. EMBO I. 13: 6062-6075.

Dreyfuss, G., M.S. Swanson, and S. Piñol-Roma. 1988. Heterogeneous nuclear ribonucleoprotein particles and the pathway of mRNA formation. Trends Biochem. Sci. 13: 86-91.

Dreyfuss, G., M.J. Matunis, S. Piñol-Roma, and C.G. Burd. 1993. hnRNP proteins and the biogenesis of mRNA. Annu. Rev. Biochem. 62: 289-321.

Fischer, U., J. Huber, W.C. Boelens, I.W. Mattai, and R. Lührmann. 1995. The HIV-1 Rev activation domain is a nuclear export signal that accesses an export pathway used by specific cellular RNAs. Cell 82: 475-483.

Flach, J., M. Bossie, J. Vogel, A.H. Corbett, T. Jinks, D.A. Willins, and P.A. Silver. 1994. A yeast RNA-binding protein shuttles between the nucleus and the cytoplasm. Mol. Cell Biol. 14: 8399-8407.

Guiochon-Mantel, A., K. Delabre, P. Lescop, and E. Milgrom. 1994. Nuclear localization signals also mediate the outward movement of proteins from the nucleus. Proc. Nat. Acad. Sci. 91: 7179-7183.

Haynes, S.R. 1992. The RNP motif protein family. New Biol. 4: $421-429$.

Henry, M., C.Z. Borland, M. Bossie, and P.A. Silver. 1996. Potential RNA binding proteins in Saccharomyces cerevisiae identified as suppressors of temperature-sensitive mutations in NPL3. Genetics 142: 103-115.

Hill, J.E., A.M. Myers, T.J. Koerner, and A. Tzagoloff. 1993. Yeast/E. coli shuttle vectors with multiple unique restriction sites. Yeast 2: 163-167.

Jarmolowski, A., W.C. Boelens, E. Izaurralde, and I.W. Mattaj. 1994. Nuclear export of different classes of RNA is mediated by specific factors. I. Cell Biol. 124: 627-635.

Kadowaki, T., S. Chen, M. Hitomi, E. Jacobs, C. Kumagai, S. Liang, R. Schneiter, D. Singleton, J. Wisniewska, and A.M. Tartakoff. 1994a. Isolation and characterization of Saccharomyces cerevisiae mRNA transport-defective $\{\mathrm{mtr}\rangle \mathrm{mu}$ tants. J. Cell Biol. 126: 649-659.

Kadowaki, T., M. Hitomi, S. Chen, and A.M. Tartakoff. 1994b. Nuclear mRNA accumulation causes nucleolar fragmenta- tion in yeast mtr2 mutant. Mol. Biol. Cell 5: 1253-1263.

Kadowaki, T., Y. Zhao, and A.M. Tartakoff. 1994c. A conditional yeast mutant deficient in mRNA transport from the nucleus to the cytoplasm. Proc. Nat. Acad. Sci. 89: 23122316.

Kadowaki, T., R. Schneiter, M. Hitomi, and A.M. Tartakoff. 1995. Mutations in nucleolar proteins lead to nucleolar accumulation of poly(A) $)^{+}$RNA in Saccharomyces cerevisiae. Mol. Biol. Cell 6: 1103-1110.

Kahana, J.A. and P.A. Silver. 1996. Use of a A. victoria green fluorescent protein to study protein dynamics in vivo. In Current protocols in molecular biology (ed. F.M. Ausubel, R. Brent, R.E. Kingston, D.E. Moore, J.G. Seidman, J.A. Smith, and K. Struhl), Vol. 1, pp. 9.6.13-9.6.19. John Wiley \& Sons, Greene, New York, NY.

Kenan, D.J., C.C. Query, and J.D. Keene. 1991. RNA recognition: Toward identifying determinants of specificity. Trends Biochem. Sci. 16: 214-220.

Kranz, J.E. and C. Holm. 1990. Cloning by function: An alternative approach for identifying yeast homologs from other organisms. Proc. Nat. Acad. Sci. 87: 6629-6633.

Loeb, J.D.L., G. Schlenstedt, D. Pellman, D. Kornitzer, P.A. Silver, and G. Fink. 1995. A nuclear import receptor homologue required for mitosis in yeast. Proc. Nat. Acad. Sci. 92: 76477651.

Loo, S., P. Laurenson, M. Foss, A. Dillin, and J. Rine. 1995. Roles of $A B F 1, N P L 3$, and YCL54 in silencing in Saccharomyces cerevisiae. Genetics 141: 889-902.

Mattaj, I.W. 1993. RNA recognition: A family matter? Cell 73: $837-840$.

Mehlin, H. and B. Daneholt. 1993. The balbani ring particle: A model for the assembly and export of RNPs from the nucleus? Trends Biochem. Sci. 3: 443-447.

Michael, W.M., M. Choi, and G. Dreyfuss. 1995. A nuclear export signal in hnRNP Al: A signal-mediated, temperaturedependent nuclear protein export pathway. Cell 83: 415422.

Nonet, M., C. Scafe, I. Sexton, and R. Young. 1987. Eucaryotic RNA polymerase conditional mutant that rapidly ceases mRNA synthesis. Mol. Cell. Biol. 7: 1602-1611.

Oakes, M., Y. Nogi, M.W. Clark, and M. Nomura. 1993. Structural alterations of the nucleolus in mutants of Saccharomyces cerevisiae defective in RNA polymerase I. Mol. Cell. Biol. 13: 2441-2445.

Orr-Weaver, T.L. and I.W. Szostak. 1983. Yeast recombination: The association between double-stranded gap-repair and crossing over. Proc. Natl. Acad. Sci. 80: 4417-4421.

Peters, R. 1986. Fluorescence microphotolysis to measure nucleocytoplasmic transport and intracellular mobility. Biochim. Biophys. Acta 864: 305-359.

Pinol-Roma, S. and G. Dreyfuss. 1991. Transcription-dependent and transcription-independent nuclear transport of hnRNP proteins. Science 253: 312-314.

- 1992. Shuttling of pre-mRNA-binding protein between nucleus and cytoplasm. Nature 355: 730-732.

- 1993. hnRNP proteins: Localization and transport between the nucleus and the cytoplasm. Trends Biochem. Sci. 3: $151-155$.

Rose, M.D., F. Winston, and P. Hieter. 1990. Methods in yeast genetics: A laboratory manual. Cold Spring Harbor Laboratory Press, Cold Spring Harbor, NY.

Russell, I.D. and D. Tollervey. 1992. NOP3 I is an essential yeast protein which is required for pre-rRNA processing. $I$. Cell Biol. 119: 737-747.

. 1995. Yeast Nop3p has structural and functional similarities to mammalian pre-mRNA-binding proteins. Eur. $I$. 
Cell Biol. 66: 293-301.

Schlenstedt, G., E. Hurt, V. Doye, and P.A. Silver. 1993. Reconstitution of nuclear protein transport with semi-intact yeast cells. J. Cell Biol. 123: 785-798.

Schmidt-Zachermann, M.S., C. Dargemont, L.C. Kuhn, and E.A. Nigg. 1993. Nuclear export of proteins: The role of nuclear retention. Cell 74: 493-504.

Sikorski, R.S. and P. Hieter. 1989. A system of shuttle vectors and yeast host strains designed for efficient manipulation of DNA in Saccharomyces cerevisiae. Genetics 122: 19-27.

Singleton, D.R., S. Chen, M. Hitomi, C. Kumagai, and A.M. Tartakoff. 1995. A yeast protein that bidirectionally affects nucleocytoplasmic transport. I. Cell Sci. 108: 265-272.

Siomi, H. and G. Dreyfuss. 1995. A nuclear localization domain in the hnRNP Al protein. I. Cell Biol. 129: 551-560.

Tani, T., R.J. Derby, Y. Hiraoko, and D.L. Spector. 1995. Nucleolar accumulation of poly $(A)^{+}$RNA in heat-shocked yeast cells: Implication of nucleolar involvement in mRNA transport. Mol. Biol. Cell. 6: 1515-1534.

Tipper, D.J. 1973. Inhibition of yeast ribonucleic acid polymerases by thiolutin. I. Bacteriol. 116: 245-256.

Visa, N., A.T. Alzhanova-Ericsson, X. Sun, E. Kiseleva, B. Björkroth, T. Wurtz, and B. Daneholt. 1996. A pre-mRNA-binding protein accompanies the RNA from the gene through the nuclear pores and into the polysomes. Cell 84: 253-264.

Weighardt, F., G. Biamonti, and S. Riva. 1995. Nucleo-cytoplasmic distribution of human hnRNP proteins: A search for the targeting domains in hnRNP A1. I. Cell Sci. 108: 545-555.

Wen, W., J.L. Meinkoth, R.Y. Tsien, and S.S. Taylor. 1995. Identification of a signal for rapid export of proteins from the nucleus. Cell 82: 463-473.

Wilson, S.M., K.V. Datar, M.R. Paddy, J.R. Swedlow, and M. Swanson. 1994. Characterization of nuclear polyadenylated RNA-binding proteins in Saccharomyces cerevisiae. J. Cell Biol. 127: 1173-1184.

Yocum, R.R., S. Hanley, R.W. West, Jr., and M. Ptashne. 1984. Use of LacZ fusions to delimit regulatory elements of the inducible divergent GAL1-GAL10 promoter in Saccharomyces cerevisiae. Mol. Cell. Biol. 4: 1985-1998.

Zasloff, M. 1983. tRNA transport from the nucleus in eukaryotic cells: Carrier-mediated process. Proc. Natl. Acad. Sci. 80: 6436-6440. 


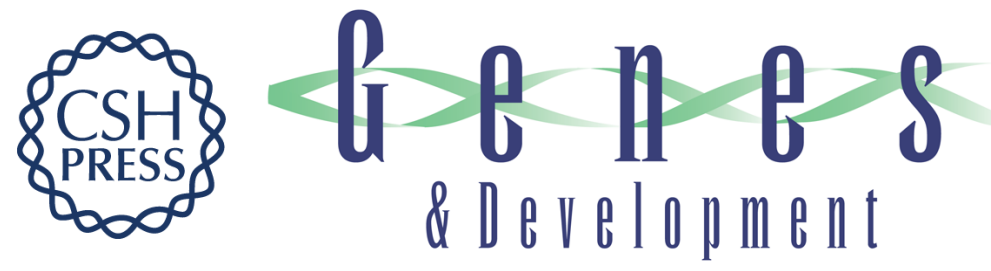

\section{A protein that shuttles between the nucleus and the cytoplasm is an important mediator of RNA export.}

M S Lee, M Henry and P A Silver

Genes Dev. 1996, 10:

Access the most recent version at doi:10.1101/gad.10.10.1233

References This article cites 51 articles, 30 of which can be accessed free at:

http://genesdev.cshlp.org/content/10/10/1233.full.html\#ref-list-1

License

Email Alerting

Service

Receive free email alerts when new articles cite this article - sign up in the box at the top right corner of the article or click here.

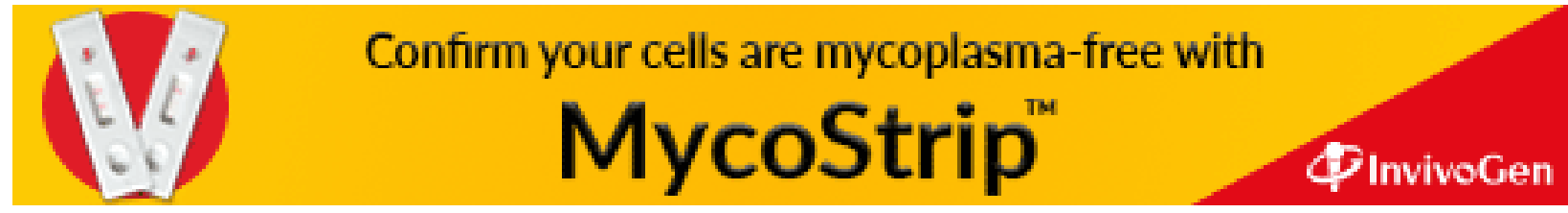

